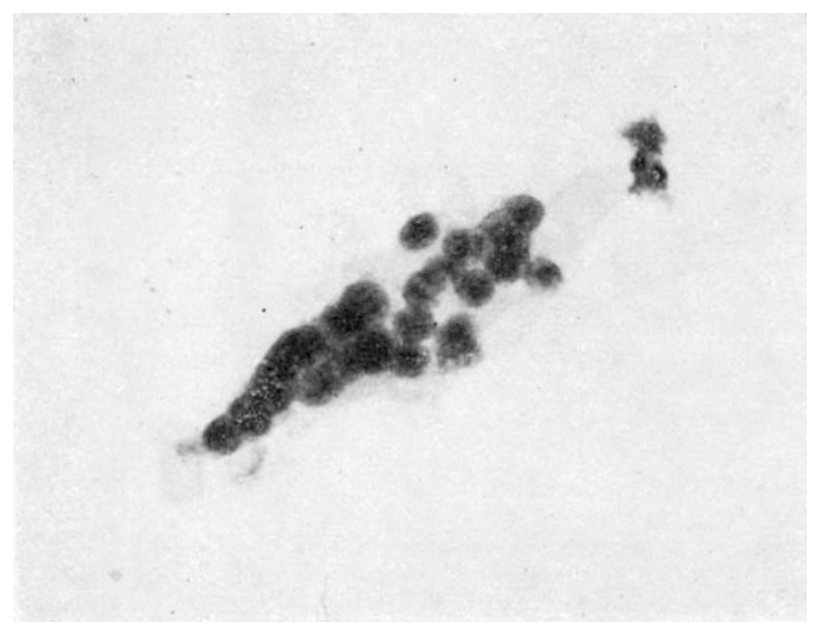
Fig. 2. Photomicrograph of syncytium $(\times 300)$ stained with haematoxy-
lin and eosin.

The specificity of the mouse anti-human trophoblast serum has been demonstrated before ${ }^{10}$. Incubation of this serum with a heterogeneous cell population cultured from early human placenta identified cells with the cytological characteristics of syncytiotrophoblast and cytotrophoblast when stained with a fluorescent labelled anti-mouse serum. Re-staining the same cells with haematoxylin and eosin also confirmed the characteristic epithelioid and syncytial appearance said to be typical of cytotrophoblast and syncytiotrophoblast respectively. Non-fluorescent cells seemed to have cytological features of blood cells when re-stained with haematoxylin and eosin. The absence of fibroblasts in these cultures suggests that trypsinization can be used to prepare cultures relatively free from cells other than trophoblast.

We thank the Wellcome Trust for their support. Pamela Rigby

Department of Obstetrics and Gynaecology,

Charing Cross Hospital Medical School, WC2.

Received February 17, 1969

1 Thiede, H. A., Amer. J. Obstet. Gynec., 79, 636 (1960).

Thiede, H. A. Clin. Obstet. Gynec, 6, 110 (1963).

${ }^{3}$ Soma, H., Ehrmann, R. J., Hertig, A. T., Obstet. Gynec., 18, 704 (1961).

+Curric, G. A., J. Obstet. Gynec. Brit. Commonwealth, 74, 84 (1967).

5 Wislocki, G. B., and Dempsey, E. W., Endocrinology, 38, 90 (1946).

'Botello, J., Cano, A., Arch. Med. Exp. (Mådrid), 13, 45 (1950).

: Dumont, M., Piesse Med, 65, 535 (1957).

- Thomsen, K., Geburtsh Frauenheilk, 18, 354 (1958).

- Curzen, P., J. Obstet. Gynec. Brit. Commonwealth, 74, 385 (1967).

${ }^{0}$ Curzen, P., J. Obstet. Gynec. Brit. Commonwealth, 75, 1128 (1968).

\section{Interrelationship between Plasma Luteinizing Hormone and Oestradiol in the Human Menstrual Cycle}

Oestrogens have a feedback action on the central nervous system ${ }^{x}$. They are implicated in the regulation of human luteinizing hormone (HLH), high concentrations of oestrogen being associated with low concentrations of HLH and vice versa ${ }^{2}$.

Urinary oestrogen excretion has been compared with urinary gonadotrophins ${ }^{3}$ and plasma $\mathbf{H L H}^{4}$ during the menstrual cycle, a midcycle rise of both hormones being reported in each case.

Wo have determined HLH and $I 7 \beta$-oestradiol in plasma collected daily throughout the menstrual cycle, from five regularly menstruating women. H.L.H was measured by double antibody radioimmunoassay ${ }^{5}$ and oestradiol by competitive protein binding ${ }^{6}$.
Fig. 1 shows the results obtained during the first three individual cycles on samples collected at the same time each day $(1000-1030 \mathrm{~h})$. Each point is the mean of duplicate determinations with an average error of \pm 10 per cent. Where the error exceeded \pm 20 per cent the range between duplicates has been indicated.

In all five cycles the results demonstrate a midcycle rise in the circulating levels of both oestradiol and $H L H$, the peak of oestradiol occurring on the day before the day of maximum HLH concentration $(P=0 \cdot 03)^{?}$. It is noteworthy that the HLH starts to rise before the oestradiol peak is reached.

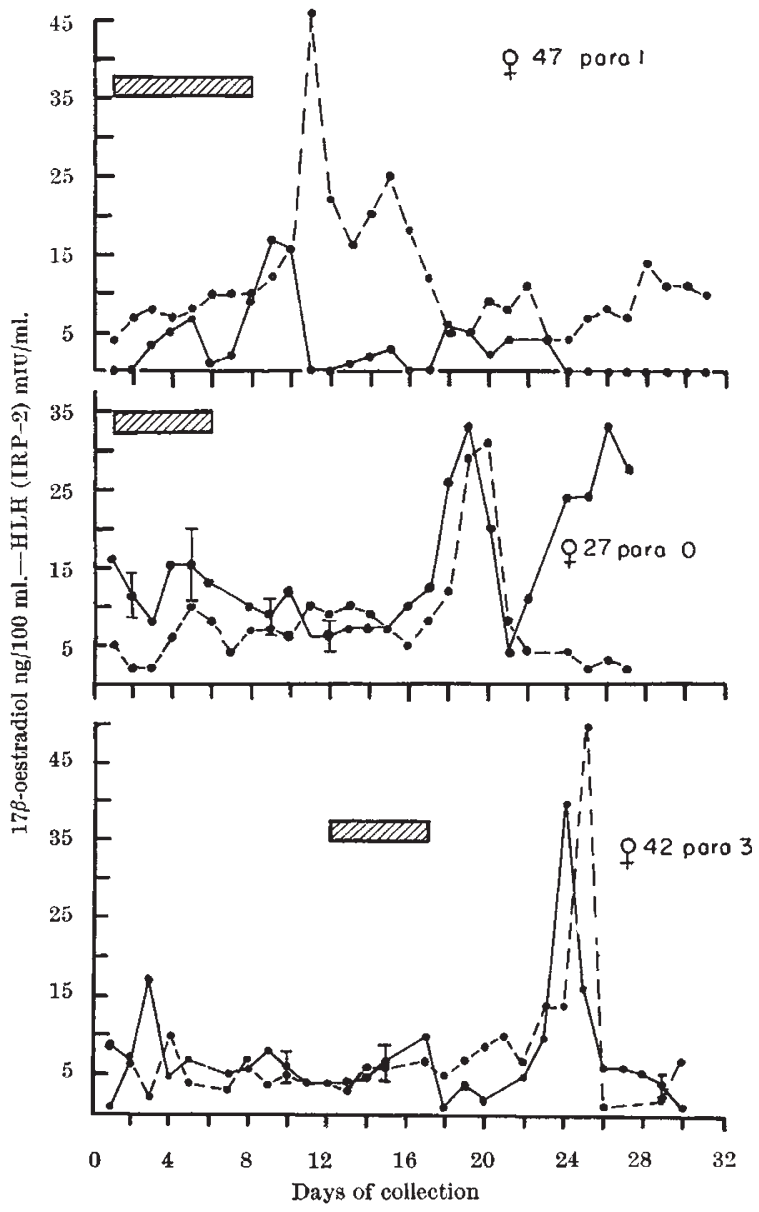

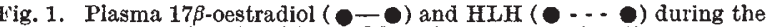
menstrual cycle. Hatched bars indicate menstruation.

Part of this work was supported by an MRC grant. F. N. is a special research fellow, National Institute of Child Health and Human Development, US Public Health Service.

MRC Neuroendocrinology Unit,

C. S. CoRKer

F. NAFTOLIN

D. EXLEY

Department of Human Anatomy,

University of Oxford.

Received March 3; revised May 5, 1969.

${ }^{1}$ Harris, G. W., in The Pituitary Gland, 2 (edit. by Harris, G. W., and Donovan, В. T.), 99 (Butterworth, London, 1966).

2 Odell, W. D., Ross, G. T., and Rayford, P. L., J. Clin. Invest., 46, 248 (1967)

${ }^{3}$ Brown, J. B., Klopper, A., and Loraine, J. A., J. Endocrinol., 17, 401 (1958).

${ }^{4}$ Burger, H, G., Catt, K. J, and Brown, J, B, J. Clin. Endocrinol., 28, 1508 (1968).

${ }^{5}$ Naftolin, F., Espeland, D., Tremann, J. A., Dillard, E. A., and Paulsen, C. A., in Gonadotrophins 1968 (edit. by Rosemberg, E.) (Geron-x, Los Altos, California, 1968)

' Corker, C. S., and Exley, D., J. Endocrinol., 43, XXX (1969).

' Siegel, S., in One Tailed Binomial Test in Nonparametric Statistirs for Behavioural Sciences, 36 (McGraw-Hill, New York, 1956). 